\title{
An introduction to multiple perspectives on Davydov's approach in the XXI century
}

\author{
Linda Venenciano $^{1} \cdot$ Elena Polotskaia $^{2}$ (D) Maria Mellone $^{3} \cdot$ Luis Radford $^{4}$
}

Accepted: 10 February 2021 / Published online: 4 March 2021

(C) The Author(s), under exclusive licence to Springer Nature B.V. part of Springer Nature 2021

In many countries, the twentieth century philosophy and social sciences were marked by a dialectical materialist understanding of humans and the world. This understanding revolves around the idea that human collective activity and material and ideational culture (e.g., symbols, language) play a central role in learning and development. In socialist Russia, dialectical materialist was the main philosophy that shaped research in psychology and education. This philosophy is the foundation of the work of L. S. Vygotsky and his followers, Vasil V. Davydov (1930-1998) among them. Davydov studied the philosophy of dialectical and historical materialism and the pedagogical psychology under the supervision of Piotr Galperin - one of the former students of Lev Vygotsky — at the Russian State University in Moscow. From 1953 Davydov worked together with Galperin, Daniil El'konin, and others to study, from the theoretical point of view, the psychological processes of conceptual knowledge acquisition in primary school children. Following the Vygotskian idea that learning can nurture the cognitive and psychological development of the learner, the group worked on new curricula as well as new teaching approaches that would strongly support this development in a child and ensure sustainable knowledge acquisition in the future. Years of theoretical and experimental work of Davydov's laboratory gave rise to a radically new curricula content and new approach to teaching and learning in elementary school. Inspired by the materialist

Elena Polotskaia

elena.polotskaia@uqo.ca

Linda Venenciano

lhirashi@hawaii.edu

Maria Mellone

maria.mellone@unina.it

Luis Radford

lradford@laurentian.ca

1 University of Hawai'i, Mānoa, Honolulu, HI, USA

2 Université du Québec en Outaouais, Gatineau, Canada

3 University Federico II of Naples, Naples, Italy

4 Laurentian University, Sudbury, Canada 
dialectics of Evald Ilyenkov (e.g., 2018), Davydov (2008) integrated multiple educational theories to articulate the theory of developmental instruction.

The theory of developmental instruction takes its roots in Vygotsky's groundbreaking work on the nature of the psychological processes underpinning learning and teaching in a cultural, historical, and social setting. Vygotsky's work has led to further developments by the Kharkov group (Leontiev, 2011) and extended lines of work, such as Galperin's conception of step-bystep formation of mental actions (Haenen, 1993) and Activity Theory (Leontiev, 1978). Drawing on these works, Davydov conceptualized learning as a special form of activitylearning activity. In Russian this form is called учебная деятельность (uchebnaia deiatelnost). The Russian term deiatelnost, usually translated as activity, designates a sociocultural theoretical construct explaining historically developed forms of human activities.

The concept of learning activity (uchebnaia deiatelnost) is connected to the distinction Davydov made between empirical and theoretical thinking. Although all thinking is based on generalizations, the generalizations of empirical thinking are "a primary 'idealization' of certain aspects of material life - and, above all, of those that can be observed and ascertained directly in perception" (Davydov, 1990, p. 115). Theoretical thinking, as opposed to empirical thinking, goes beyond the perceptual field and enters into the field of idealization, where the dynamic essential relations between objects come to the fore. Empirical thinking can be illustrated in a situation where a student attempts to solve a word problem by highlighting the known data and the question to be answered. In contrast, theoretical thinking enables a student to move beyond the words and numbers presented in the problem and to look for and apply an appropriate mathematical structure to solve it. When accompanied with the opportunity to communicate their thinking about the mathematical essence of the problem, a teacher can more fully evaluate the student's thinking. As Davydov put it, "[m]ediated, reflected, essential being is the substance of theoretical thought" (p. 116). He also pointed out that, "Disclosure and expression in symbols of the mediated being of things ... is a transition to the theoretical reproduction of reality" (p. 117; emphasis in the original).

The concept of learning activity (uchebnaia deiatelnost) is also connected to Davydov's revolutionary idea that runs against empiricist epistemology, namely, that the most general theoretical understanding of a phenomenon should be developed by the learner (in a specially created context) prior to mastering multiple particular cases of that phenomenon. Having at its heart this innovative idea, the theory of developmental instruction proposed by Davydov laid down a foundation to an educational system, which includes the teaching and learning of language, mathematics, arts, and sciences in elementary and middle school. The part of this system regarding mathematics education in elementary school has become known to the Western mathematics education community as the El'konin-Davydov curriculum. This curriculum revolutionized the experimental classrooms by changing the traditional "memorize and apply" into the "learn to think" in the teacher's mindset and the student's attitude.

At the end of the twentieth century, Jean Schmittau conducted the first North American implementation of the El'konin-Davydov mathematics curriculum in elementary school. Since then, the El'konin-Davydov curriculum has been attracting more and more attention from researchers in mathematics education. In 2014, researchers from different countries organized a symposium, Transforming Davydov's Learning Activity Curricula into New Contextsexamples from Canada, Italy and Sweden, which attracted important attention from the international community (Eriksson et al., 2014). This discussion initiated a publication project with the International Journal for Mathematics Teaching and Learning in a special issue featuring contemporary research on the El'konin-Davydov curriculum (Eriksson \& Polotskaia, 
2017). A second symposium, V. V. Davydov: Philosophy, influences, and educational ideas, was held in Canada in 2017 (Radford et al., 2017). Most recently, in 2018, the colloquium Foregrounding Davydov's curriculum: Relational approach and algebraic thinking in early grades was presented at the 42nd Annual Conference of the International Group for the Psychology of Mathematics Education (Polotskaia \& Sabena, 2018).

This special issue continues the international exchange behind the incredibly generative research ground - the El'konin-Davydov curriculum-looking at the subject from various perspectives. Luis Radford discusses the dialectical materialist background of the DavydovEl'konin curriculum to address the crucial vision of the concept of concept behind it. Freiman and Fellus undertake a historical perspective to allow the reader to plunge into the Soviet algebra debates surrounding the appearance of the El'konin-Davydov curriculum and discuss the role of the learning activity (uchebnaia deiatelnost) in the knowledge construction process. Eriksson and Eriksson explore the connection between arithmetic and algebraic thinking in a multilingual classroom context. Mellone, Ramploud, and Carotenuto share an Italian experimentation on the Davydov's curriculum by the particular theoretical perspective of cultural transposition. Venkat, Askew, and Morrison present adaptations within the South African context. Venenciano, Yagi, and Zenigami analyze first grade students' relational thinking development within the symbolic rich Measure Up curriculum, a US version of the Davydov approach. Vysotskaya, Lobanova, Rekhtman, and Yanishevskaya present further theoretical and experimental explorations of the fundamental ideas of the Davydov theory of developmental instruction, by reflecting on the proportional reasoning and the concept of ratio-its genetics and epistemology. Finally, starting from Davydov's crucial theoretical study, Polotaskaia and Savard propose an implementation of the notion of the quantitative relationship for multiplicative thinking development. Commentary provided by Alf Coles and a tribute to the work of Dr. Jean Schmittau provided by Rachel Bachman complete this special collection of papers.

Educational Studies in Mathematics represents one of the most prestigious journals to share studies and research experiences in our field. Through this special issue, the journal offers the community of mathematics educators an important space of international exchange and dialogue on the El'konin-Davydov curriculum. We are convinced that this special issue represents a fresh starting point from where we can continue exploring Davydov's crucial and penetrating ideas, which, as Jean Schmittau (1937-2015) once suggested, go perhaps beyond Davydov's own previsions and deserve further investigation.

\section{References}

Davydov, V. V. (1990). Types of generalization in instruction: Logical and psychological problems in the structuring of school curricula. (J. Teller, Trans. Reston, Virginia: The National Council of Teachers of Mathematics.

Davydov, V. V. (2008). Problems of developmental instruction: A theoretical and experimental psychological study. New York: Nova Science.

Eriksson, I., Fermsjö, R., Mellone, M., Eriksson, H., \& Polotskaia, E. (2014, Sept). Transforming Davydov's learning activity curricula into new contexts - examples from Canada, Italy and Sweden. In I. Eriksson (Chair), Symposium conducted at the meeting of ISCAR $4^{\text {th }}$ International congress, Sydney.

Eriksson, I., \& Polotskaia, E. (2017). Editorial. International Journal for Mathematics Teaching and Learning, 18(2), 132-135.

Haenen, J. (1993). Piotr Gal'perin. Amsterdam: OMI, Universiteit Utrecht. 
Ilyenkov, E. (2018). Intelligent Materialism : essays on Hegel and dialectics. Koninklijke Brill NV.

Leontiev, A. N. (1978). Activity, consciousness, and personality. Englewood Cliffs: Prentice-Hall.

Leontiev, A. N. (2011). Kharkov school of psychology (Harkovskaia psikhologi cheskaia shkola). CulturalHistorical Psychology, 3, 134-139.

Polotskaia, E., \& Sabena, C. (2018). Colloquium: Foregrounding Davydov's curriculum: Relational approach and algebraic thinking in early grades. In E. Bergqvist, M. Österholm, C. Granberg, \& L. Sumpter (Eds.), Proceedings of the 42nd Conference of the International Group for the Psychology of Mathematics Education (vol. 1). Umeå: PME.

Radford, L., Freiman, V., Eriksson, H., \& Polotskaia, E. (2017). V. V. Davydov: Philosophy, influences, and educational ideas. L. Radford and I. Eriksson. (Chairs), Symposium conducted the meeting of the ISCAR $5^{\text {th }}$ ISCAR International congress, Quebec.

Publisher's note Springer Nature remains neutral with regard to jurisdictional claims in published maps and institutional affiliations. 